\title{
A Study on the bacterial flora and its significance in the housefly, Musca domestical L. (Diptera : Muscidae)
}

\author{
Mostafa I. Hassan ${ }^{1}$, Zaineb M. El-Basheer ${ }^{2}$, Eman M. Rashad ${ }^{2}$ and \\ Marwa M. Abo-El-Maaty ${ }^{2}$. \\ ${ }^{1}$ Zoology Department, Faculty of Science, Al-Azhar University, Cairo. \\ ${ }^{2}$ Zoology Department, Faculty of Science, Zagazig University
}

\begin{abstract}
The microbial flora associated with the housefly, Musca domestica were isolated and their influence on some biological parameters of the fly was studied. The microbial flora isolation was carried out by using different selective and non-selective media. The examination of the housefly gut revealed a heavy and diverse microbial flora, these were : Enteric bacteria (Eschericia coli, Salmonella sp., Shigella sp., Pseudomonuas sp., Klebsiella sp., Proteus sp., Serratia sp.); Cocci form bacteria (Haemoltic Staphylococci and Streptococci, non-haemolytic Staphylococci and Streptococci) and Bacillus sp. Actinomycetec, yeasts and filamentous fungi were isolated only from external surface of the fly. Aposymbiotic (the gut-bacterial free) flies were obtained by feeding female flies on norofloxacine antibiotic. Hatchability, larval and pupal mortality, pupation and adult emergence were affected by elimination of bacteria from the fly gut. It was concluded that gut bacteria of the housefly are not pathogenic but their association might be mutual or even symbiotic.
\end{abstract}

\section{Introduction}

Houseflies have adapted to domestic living, feeding and breeding on human food, organic wastes and faces. The movement of houseflies between faeces and food makes them ideal transmitters of human disease. A vast literature has developed on this subject and was summarized by West (1951) for work published before 1950. Greenberg $(1971,1973)$ has given a full list of the organisms which have been recovered from houseflies and a detailed consideration of their relationship to human and animal diseases.

Houseflies have been found to harbor about 100 different pathogens and charged with transmitting 65 of these (Greenberg, 1965). The pathogens recovered from flies range from viruses to helminthes, and include the viruses of poliomyelitis and infectious hepatitis, the bacteria associated with cholera (Vibrio), enteric infections caused by species of Salmonella and Shigella, pathogenic Escherichia coli, haemolytic streptococci, Staphlococcus aureus, agents of trachoma, bacterial conjunct tivitis, anthrax, diphtheria, tuberculosis, leprosy and yaws. In addition flies can carry the cysts of protozoa, including those of Entamoeba histolytica which causes amoebic dysentery, and the eggs of the threadworm Trichuris trichiura, the hookworm Ancylostoma duodenale and of other nematodes and cestodes.

The present work aimed firstly, to isolate and identified the different microbial flora associated with the female housefly, Musca domestica, Secondly; to study the effect of gut microbial flora on preoviposition 
A Study on the bacterial flora and its significance in the housefly,....

period, hatchability, larval and pupal mortality percent, pupation and adult emergence.

\section{Materials And Methods}

Insect used and maintenance of culture:

The insect used in the present study were the housefly, Musca domestica L. A stock colony of this fly species was raised for several generations in the laboratory of Medical Entomology, Faculty of Science, AlAzhar University, Cairo at $25 \pm 2^{\circ} \mathrm{C}$ and $50-60 \%$ R.H. the rearing technique was carried out according to the method of Busvine (1962).

\section{Elimination of gut bacteria of Musca domestica females:}

Newly emerged fifteen flies were collected from established colony and placed in a glass cylinder measured $15 \times 10 \mathrm{~cm}$, its top covered with a muslin tissue with a small hole. These flies were left to fed on $10 \%$ sugar solution added to it $14 \mu \mathrm{g} / \mathrm{ml}$ Norofloxacine antibiotic for three days. After this period each fly were transferred to another cylinder. Two small Petri dishes $(2.5 \mathrm{~cm}$. diam.) were placed inside each cylinder. The first dish contains a cotton pad saturated with $10 \%$ sugar solution, and the second dish contains a cotton pad saturated with $10 \%$ milk solution.

\section{Examination of gut microbial flora of Musca domestica:-}

Ten specimens of housefly, Musca domestica were carefully kept alife in sterile stoppeered glass tubes. Then they were separately dipped in $95 \%$ ethanol for two seconds, and then placed for equal period in $10 \%$ sodium thiosulfate (Poinar, et al, 1978 and Hassan et al., 2001). After the external surface has been sterilized, the specimens were rinsed for three consecutive times in sterile distilled water and were dissected under aseptic condition using sterile minute needles. The gut of each specimen was taken separately and diluted in $5 \mathrm{ml}$. of sterile saline solution. Fifty $\mu$ of $10^{-3}$ dilution of each sample was streaked on plates of different selective and non-selective microbio ogical agar media. Vital counts of the developed microorganisms of each specimen were recorded after an incubation time of $24-48 \mathrm{~h}$. for bacteria at $30^{\circ} \mathrm{C}$. Identification of microbial flora was carried out accor ding to Keys constructed by (Kreig, 1989 and Holt et al., 1994).

\section{Antimicrobial susceptibility:-}

The antimicrobial susceptibility of selected 10 purified bacterial culture of gut flora of different investigated flies was examined by disk diffusion method (Bauer et al, 1966). Bacterial cultures maintained on nutrient agar slants or blood agar slant in case of fastidious organisms were grown in nutrient broth or nutrient broth supplemented with $5 \%$ sheep blood for $18 \mathrm{~h}$. at $37^{\circ} \mathrm{C}$. A volume of 0.1 of the diluted culture equivalent to $10^{6} \mathrm{CFU} / \mathrm{ml}$. was mixed with sterile nutrient agar (or blood agar) plates. The disks of the following antimicrobial agents (BBL) were used.: Ampicillin (AM. 10mg), Kanamycin (K,30mg), Carbencillin ( CB,100 mg), Rifampicine (RA, $30 \mathrm{mg}$ ), Sulfa (SXT, 25mg), Nitrofuration (FD, 300mg), Tetracycline (TE,30mg), Natidixic acid (NA, 30mg) and Norofloxacine (NOR, 30mg).

\section{Effect of gut bacteria on some biological aspects of Musca domestica: \\ After $48 \mathrm{~h}$. the males flies were} excluded and the female flies were left to study the effect of bacterial 
elimination from the gut on number of eggs laid, preoviposition period hatchability, larval and pupal mortality, pupation and adult emergence. A control group was used as the treated one and fed on the same media, without adding antibiotic and the pervious developmental aspects were recorded.

Statistical analysis of the data was carried out according to the method of Lentner et al. (1982).

\section{Results}

Microbial flora associated with the housefly Musca domestica:

The microbial examination of the housefly, Musca domestica revealed a heavy and very diverse microbial flora which can be summarized in table (1) and (2). The isolated bacteria from the housefly either externally or internally were found to belong to Escherchia coli, Salmonella sp., Shigella sp., Pseudomonas sp., Klebsiella sp., Proteus, serratia sp. and Bacillus sp.

Tables (1) and (2) showed the absence of Haemohilus bacteria either externally or internally (in the gut), while non-haemolytic Staphylococci and Streptococci represented $100 \%$ in both isolated sites. Also it was noticed from table (1) that actinomycetes, yeasts and filamentous fungi were isolated only from the external surface of the housefly, while they were completely disappeared from the housefly gut.

Data in tables (1) and (2) showed that enteric bacteria represented 20 and $79 \%$ of all isolated bacteria from the external surface and the gut; respect tively, while cocci form bacteria recorded the lowest percent in the two examined sites. It was also noticed that Escherchia coli represented $73 \%$ of all enteric bacteria isolated, while
Pseadonomas: Klebsiella, Proteus and Serratia represented $11 \%$ of the enteric bacteria in the gut of the housefly.

As regards, Salmonella and Shigella were represented only by $1 \%$ and $16 \%$ of enteric bacteria isolated from external surface and gut; respectively.

\section{Elimination of gut bacterial flora of female Musca domestica:}

The data presented in table (3) showed that the norfloxacine antibiotic was the most effective agent against: Escherchia coli, Salmonella sp., Pseudomonas sp., Staphylococcus sp. and Streptococcus sp. thus it is used in the present work to eliminate these bacterial species from the gut of Musca domestica female. Other antimicrobial agents tested were less effective than norfloxacine on the previous bacterial species.

\section{Effect of the isolated midgut bacteria on different biological aspects of Musca domestica:}

The data in table (4) showed that the mean number of eggs laid was decreased in the midgut-bacterial free females compared to $136 \pm 7.82$ for the control ones to $111.4 \pm 8.92$. The bacterial elimination from the gut was fount to greatly affect on the hatchability percent, where the hatcha bility percent was highly significantly reduced to $59.6 \%$ compared to $96.5 \%$.

The data recorded in table (5) revealed that the larval mortality was increased to $8.4 \%$ in midgut-bacterial free flies, while it was $3.5 \%$ in the control group. On the other hand the pupal mortality was $8.0 \%$ in the midgutbacterial free flies and $1.8 \%$ in the control group. 
A Study on the bacterial flora and its significance in the housefly,....

Table (1) Percentage of Microbial flora associated with external surface and gut of the house fly, Musca domestica.

\begin{tabular}{|c|c|c|}
\hline Microbial flora & $\begin{array}{c}\text { External surface } \\
\% \\
\end{array}$ & $\begin{array}{c}\text { Gut } \\
\% \\
\end{array}$ \\
\hline Haemophilus sp. & 0 & 0 \\
\hline $\begin{array}{c}\text { Enteric bacteria } \\
\text { 1- Eschericia coli } \\
\text { 2- Salmonella sp. and Shigella sp. } \\
\text { 3- Psedomonus sp., Klebsiella sp., } \\
\text { Proteus sp. and Serratia sp. }\end{array}$ & $\begin{array}{c}20 \\
70 \\
1 \\
29\end{array}$ & $\begin{array}{l}79 \\
73 \\
16 \\
11\end{array}$ \\
\hline $\begin{array}{c}\text { Cocci form bacteria } \\
\text { 1- Haemolytic staphylococci } \\
\text { and Streptococci } \\
\text { 2- Non-haemolytic staphylococci } \\
\text { and streptococci }\end{array}$ & $\begin{array}{c}20 \\
0 \\
100\end{array}$ & $\begin{array}{c}21 \\
0 \\
100\end{array}$ \\
\hline Bacillus sp. & 60 & 10 \\
\hline Actinomycetes & $1.5 \times 10^{6}$ & 0 \\
\hline Yeasts & $0.04 \times 10^{6}$ & 0 \\
\hline Filamentous Fungi & $0.1 \times 10^{6}$ & 0 \\
\hline
\end{tabular}

*Percentage of enteric bacteria, Cocci form and Bacilli form was calculated relatively to the total count on nutrint agar *Percentage of Haemophilus sp. And Haemolytic cocci form bacteria was calculated to the total count on blood agar

*Amounts of Actinomycetes, Yeasts and Fungi was calculated as viable count 
Table (2) The viable count of gut bacteria associated with the house fly, Musca domestica on different selective media.

\begin{tabular}{|c|c|c|}
\hline Media used & External surface & Gut bacteria \\
\hline NA & $5.0 \times 10^{6}$ & $1.2 \times 10^{7}$ \\
SGA & $0.8 \times 10^{6}$ & $0.25 \times 10^{7}$ \\
BGA & $1.0 \times 10^{6}$ & $0.95 \times 10^{7}$ \\
SSA & $0.01 \times 10^{6}$ & $0.15 \times 10^{7}$ \\
EMB & $0.7 \times 10^{6}$ & $0.7 \times 10^{7}$ \\
BA & $1.2 \times 10^{6}$ & - \\
AZBA & - & - \\
HA & - & - \\
Litt & - & - \\
\hline
\end{tabular}

Where: NA $=$ Nutrient agar, SGA $=$ Ston gelatin agar, BGA $=$ Brilliant green agar, SSA $=$ Salmonella and Shigella agar, EMB = Eosin methylene blue agar, BA = Blood agar, AZBA = Azid blood agar, HA = Haemophilus agar and Litt = Luttman agar,

Table (3) Susceptibility test of the selected 12 bacterial isolates for 10 antimicrobial agents using the disk diffusion method.

\begin{tabular}{|l|l|l|l|l|l|l|l|l|l|l|}
\hline \multirow{2}{*}{ Bacterial strain } & \multicolumn{9}{|c|}{ Antimicrobial agents } \\
\cline { 2 - 10 } & NOR & AM & K & CB & RA & C & SXT & FD & TE & NA \\
\hline Eschericia coli & $3+$ & $2+$ & $3+$ & $2+$ & $4+$ & $2+$ & $3+$ & - & $1+$ & $2+$ \\
Salmonella sp. & $3+$ & $3+$ & $2+$ & $1+$ & $2+$ & $2+$ & $2+$ & $1+$ & $4+$ & $2+$ \\
Pseudomonus sp. & $3+$ & $1+$ & $2+$ & $2+$ & $1+$ & - & - & $2+$ & $3+$ & - \\
Staphylococcus sp. & $2+$ & $3+$ & $3+$ & $3+$ & $3+$ & $2+$ & $3+$ & $4+$ & $3+$ & $3+$ \\
Streptococcus sp. & $3+$ & $3+$ & $3+$ & $2+$ & $3+$ & $3+$ & $2+$ & $1+$ & $1+$ & $3+$ \\
\hline
\end{tabular}

Where : (NOR) Norofloxacine, (Am) Ampicillin, (K) Kanamycin, (CB) Carbenicllin, (RA) Rifampicine, (C) Chloromphenicol, (SXT) Sulfa, (FD) Nitrofurention, (TE) Tetracycline, (NA) Nalidixic acid.

Norofloxacine was used to eliminate the gut bacterial flora where it was proved to be the most effetive on different bacterial strains. 
A Study on the bacterial flora and its significance in the housefly,....

Table (4) Effect of the midgut bacterial flora on the preoviposition period, fecundity and hatchability of the house fly, Musca domestica

\begin{tabular}{|c|c|c|c|c|c|c|c|c|c|c|c|}
\hline \multirow{2}{*}{ Treatment } & \multirow{2}{*}{$\begin{array}{l}\text { No. of } \\
\text { flies } \\
\text { used }\end{array}$} & \multicolumn{2}{|c|}{$\begin{array}{l}\text { Preoviposition } \\
\text { period (days) }\end{array}$} & \multicolumn{2}{|c|}{$\begin{array}{l}\text { No. of eggs } \\
\text { laid }\end{array}$} & \multicolumn{3}{|c|}{ Non hached eggs } & \multicolumn{3}{|c|}{ Hatched eggs } \\
\hline & & range & mean \pm SE & range & mean \pm SE & range & mean \pm SE & $\%$ & range & $\operatorname{mean} \pm \mathbf{S E}$ & $\%$ \\
\hline $\begin{array}{c}\text { Midgut } \\
\text { bacterial } \\
\text { free females }\end{array}$ & 7 & $4-5$ & $4.4 \pm 0.2$ & $70-135$ & $111.4 \pm 8.92$ & $19-61$ & $44.9 \pm 8.03 * *$ & 40.4 & $10-88$ & $66.42 \pm 10.42 * *$ & 59.6 \\
\hline
\end{tabular}

Table (5) Effect of the midgut bacterial flora on the larval and pupal mortaliteis, pupation and adult emergence percent of Musca domestica

\begin{tabular}{|c|l|l|l|l|l|l|l|l|l|l|l|l|}
\hline \multirow{2}{*}{ Treatment } & \multicolumn{3}{|c|}{ Larval mortality } & \multicolumn{3}{c|}{ Pupation } & \multicolumn{3}{c|}{ Pupal mortality } & \multicolumn{3}{c|}{ Adult emergence } \\
\cline { 2 - 14 } & range & mean+SE & range & mean+SE & $\%$ & range & mean+SE & $\%$ & range & mean+SE & $\%$ \\
\hline $\begin{array}{c}\text { Normal } \\
\text { females }\end{array}$ & $2-8$ & $4.5 \pm 3.59$ & 3.5 & $26-150$ & $126.8 \pm 48.1$ & 96.5 & $1-3$ & $2.25 \pm 0.88$ & 1.8 & $93-147$ & $124.5 \pm 46.9$ & 98.2 \\
\hline $\begin{array}{c}\text { Midgut } \\
\text { bacterial free } \\
\text { females }\end{array}$ & $2-10$ & $5.57 \pm 2.57$ & 8.4 & $8-79$ & $60.85 \pm 26.5 * *$ & 91.6 & $1-23$ & $5.14 \pm 3.6$ & 8.4 & $7-78$ & $55.71 \pm 23.6 *$ & 91.6 \\
\hline
\end{tabular}

\section{Discussion}

The present data revealed that the female housefly, Musca domestica harbored both gram-negative and grampositive bacteria, also other microorg anisms in her midgut. A variety of bacterial species and genera were isolated. These bacteria were enteric bacteria which include: Eschericia coli, Salmounella sp., shigella sp., Pseudomonas sp., Klebsiella sp.,
Proteus sp. also ccoci form bacteria which include haemolytic and non haemolytic Staphylococci and Streptococci. Bacillus sp. was also isolated. Beside to these bacteria actinomycetes, yeasts and filamentous fungi were also isolated.

The present data confirm previous reports on the occurrence of bacteria in the midgut of the housefly (Greenberg, 
1965, 1973 Ghanem et al., 1986; Radi et al., 1988; Benoit et al., 1990; Schmidtmann 1992). The functional role of midgut bacteria in the adult female housefly is unknown. As regards the available literature there are no any reports concerning the effect of midgut bacterial flora on the different biological aspects of the housefly, Musca domestica. Up till now the role of these bacteria either symbiotic or non-symbiotic is unknown. The present data throw some light on the role of the midgut bacteria in the housefly. The present results showed that the occurrence of bacteria in the midgut of the fly play a very important role in the fecundity, where the number of eggs laid is affected by the elimination of bacteria. Also the hatchability percent was greatly affected by the absence of bacteria. Thus the midgut bacteria may be beneficial to the flies where they may provide the flies with some essential nutritional elements.

The reproduction inhibition induced by the elimination of digestive tract bacteria of female Musca domestica is supported by earlier investigations of Wigglesworth (1952) for the sucking lice, Pediculus and Reduviidae, Triatona and Rodinius ; Nogge $(1975,1976)$ for tsetse flies, Fouda (1984) for Hippobosca equina, Douglas (1990) and Sasaki et al. (1991) for aphid, Hassan et al. (1996) for Cx. pipiens, Hassan et al. (1998 a \& b) for the sand fly Phlebotomus papatasi, Fouda et al. (2001) and Hassan et al. (2001) for Cx. pipiens.

The decrease in the percentage of hatchability for eggs laid by midgut-free bacterial female Musca domestica may be comparable with the results obtained by Awahmukalah and Brooks (1983 \& 1985) and Hassan et al (2001) for anautogenous strain of $C x$. pipiens, where they reported that eggs of bacterial free females produced anautogenously did not hatch. Moreover, Hassan et al. (1998b) observed a decrease in the hatchability percent, which reached to $24.0 \%$ for eggs laid by aposymbiotic female sand fly, Phlebotomus papatasi.

Concerning the larval survivorship and pupation, the present data showed that the elimination of midgut bacteria of the female housefly, Musca domestica, increased morality percent of the produced larvae and pupae. Seitz et al. (1987) reported that the presence of Serratia marcescens bacteria in An. stephensi infected with Psendomonas berghei and $S$. marcescens caused a significant increase in mortality. They found that $S$. marcescens strain produ ced the exoenzymes chitinase and lecithinase which might have been responsible for the observed mortality. Thus it can be concluded that the bacteria present in the housefly midgut are not pathogenic to the flies but their association might be mutual or even symbiotic. These results are more or less in agreement with that of Awahmukalah and Brooks (1983), Pumpuni et al. (1996), Hassan et al. (2001) and Fouda, (2001).

In addition, the present data revealed that the bacterial elimination from the housefly gut reduced the percentage of adult emergence. These data are in agreement with that of Hassan et al. (2001) where they observed similar results for the aposymbiotic $C x$ pipiens.

Acknowledgement: the authors wish to express their sincere gratitude and appreciation to Dr. Hesham Mahdy assistant professor of Microbiology, Faculty of science, Al-Azhar University, for isolation and identification of bacteria used in the present work. 


\section{Refrences}

1.Awahmukalah, D. S. and Brooks, M. A. (1983): Reproduction of an inbred strain of Culex pipiens prevented by loss of Wolbachina pipientis. J. Invert. Pathol. 41, 184190.

2.Awahmukalah, D. S. and Brooks, M. A. (1985): Viability of Culex pipiens pipiens eggs affected by nutrition and aposymbiosis. $\mathbf{J}$. Invert. Pathol. 45, 225-230

3.Bauer, A. W.; Kirby, W. M. M., Sherris, J. and Turck, C. (1966): Antibiotic susceptibility testing by a standardized single disc. Method Am. J. Clin path., 45: 493-496.

4.Benoit, T. G.; Wilson, G. R.; Pryor, IV. and Bull. D. L. (1990): Isolation and Pathogenicity of Serratia marcescens from adult house flies infected with Entomophthora musca, J. Invert. Pathol. 55, 142-144.

5.Busvine, J. R. (1962): A Laboratory technique for measuring the suscep tibility of house flies to insecticides. Lab. Prot. 11: 464-465.

6.Douglas, A. E. (1990): Nutritional interactions between Myzus persicae and its symbionts. In aphid-plant Genotype interactions (Eds Campbell R. K. and Eikenbary R. D.) 319-328. Elsevier, Amsterdam.

7.Fouda, M. A. (1984): Significance of symbionts in Hippobosca equine L. (Diptera: Hippoboscidae): Z. Ang. Ent. 97, 376-378.

8.Fouda, M. A.; Hassan, J. J., AlDaly, A. G. and Hammad, K. M. (2001): Effect of midgut bacteria of Culex pipiens $\mathrm{L}$. on digestion and reproduction. J. Egypt. Soc. Parasit. 31, No. 3. Dec. 767-780.

9.Ghanem, E. H.; Hassan, M. I.; Gazal, S. A.; El-Sherawi, M. H. and Ali, O. A. (1986): Studies on bacterial flora associated with three species of blood sucking flies (Diptera). Egyptian Society of Applied Microbiology, Proc. VL. Cof. Microbiol. Cairo, 1-part (3). Taxonomy paper No. 22.

10. Greenberg, B. (1965): Flies and disease. Scientific American 213(1), 92-99

11. Greenberg, B. (1971): Flies and Disease. I Ecology, Classification and Biotic Associations. Princeton University Press, Princeton, New Jersy.

12. Greenberg, B. (1973): Flies and disease. 11. Biology and Disease Transmission. Princeton University press, Princeton, New Jersy

13. Hassan, M. I.; Fouda, M. A.; AlDaly, A. G. And Hammad, K. M. (2001): Survivorship and develop ment of Culex pipiens mosquitoes as influenced by their midgut bacterial association Sc. J. A2. Med. Fac. (Girls) 22, No. j Jan. 395 - 409.

14. Hassan, M. I.; Lotfy, N. M. and Mahdy, H. (1998b): Blood digestion Period and egg develop ment in aposymbiotic Phelbotamu papatasi Scopoli. (Diptera: Psychodidae). Proc. Egypt. Acad. Sci. 48, 191 - 206.

15. Hassan, M. I.; Mahdy, J. and Lotfy, N. M. (1998a): Biodiversity of the microbial flora associated with two species of the sand flies Phlebotomus papatasi and $P$. Ingeroni (Diptera: Psychodidae). J. Egypt. Ger. Soc. Zool., 26 (E). Entomology, 25 - 36 .

16. Hassan, M. I.; Zayed, A. B. and Ahmad, M. S. (1996): The influence of symbiotic bacteria on digestion and yolk protein synthesis in Culex pipiens L. (Diptera: Culicidae). J. Egypt Ger. Soc. Zool., 21 (E). $269-284$.

17. Holt, J. G.; Kieg, N. R.; Sneath, P. A.; Staley, J. T. and Williams, S. 
T. (1994): Bergey's manual of Determinative bacteriology $\quad\left(9^{\text {th }}\right.$ Ed.), Williams \& Wilkins, Baltimor, (14 ${ }^{\text {th }}$ Ed.) Lebanon, 145-147.

18. Kreig, N. R. (1989): Bergeys manual of systematic bacteriology. Williams and Wilkins, Baltimore.

19. Lentner, C.; Lentner, C. and Wink, A. (1982): Student's tdistribution tables. In Geigy scient ific table's 2. International medical and pharmaceutical information, Ciba-Geigy Limited, Basal, Switzerland.

20. Nogge, G. (1975): Zur bedeutung der endosymbionten fur die tests efliege. Glossina morsitans west wood. Verh. Dtsch. Zool. Ges. 159.

21. Nogge, G. (1976): Sterility in tsetse flies (Glossina morsitans westwood) caused by loss of Symbionts. Experiential, 32: 995.

22. Poinar, O. J. Geroge, R. and Thomas, M. Gerad, (1978): Diagnostic manual for the identify cation of insect pathogens plenum press New York and London.

23. Pumpuni, C. B.; Demaio, J.; Kent, M.; Davis, J. R. and Beier, J. C. (1996): Bacterial population dyna mics in three anopheline species: impact on Plasmodium sporogonic development. American Journal of Tropical Medicine and Hygiene, 54, 214-218.
24. Radi, H. M., Shoukry, A. M.; and Hafez, A. G. (1988): Evidence of a biological mode of transmission of enteric bacteria by Musca domestica J. of the Egyptian - Society - of Para - cytology. 18: (2), 457 - 462.

25. Sasaki, T; Hayashi, H. and Ishikawa, H. (1991): Growth and reproduction of the symbiotic and aposymbiotic pea aphids, Acyrthosiphon pisum maintained on artificial diets. J. Insect Physiol. 37, 749-756.

26. Schmidtmann, E. T.; Martin, P. A. W. (1992): Relationship between selected bacteria and the growth of immature house flies, Musca domestica, in an axenic test system. J. of Medical. Ento., 29: (2), 233235.

27. Seitz, H. M.; Maier, W. A.; Rottok, M. and Becker-Feldmann, H. (1987): Concomitant infections of Anopheles Stephensi with Plasmodium berghei and Serratia marcescens: additive detrimental effect. Zentralb. Bakt Hyg. 266, 155-166.

28. West, L. S. (1951): The Housefly. Comstock Publishing Company, New York.

29. Wigglesworth, V. B. (1952): Symbiosis in blood-sucking insects. Tijdschr. V. Entom. 95, 63-69. 
A Study on the bacterial flora and its significance in the housefly,....

\title{
دراسة علي الفلورا البكتيرية و معنويتها في الذبابة المتزلية مسكا دومستيكا (ذات الجناحين : مسيدي )
}

\author{
مصطفي إبراهيم حسان(1) ،زينب محمد البشير (2) ،إيمان محمد رشاد (2) \\ مروة ابو المعاطي(2) \\ قسم علم الحيوان ، كلية العلوم (بنين)- جامعة الأزهر \\ قسم علم الحيوان ، كلية العلوم - جامعة الزقازيق

تم عزل الفلورا البكتيرية المصاحبة للذبابة المتزلية ،مسكا دوومستيكا وتم دراسة تأثيرها علي بعض الظواهر البيولوجية للذبابة. تم عزل الفلورا البكتيرية باستخدام أوساط اختيارية وغير اختيارية. بفحص معى الذبابة المتزلية تم عزل وتعريف أنواع متنوعة وكثيفة من الفلورا الميكروبية مثل اثرشيا كحــولاي 6مسالمونيلا ، شيجلا ، بسيدوموناس ، كليبسلا ، بروتس ، سيراتيا. كما تم عزل انواع محللة وغــير محللة للدم مثل ستافيلوكوكاي و ستترتبوكوكاي. وتم عزل باسيلس. هذا بالإضافة إلي اكتينومايتس

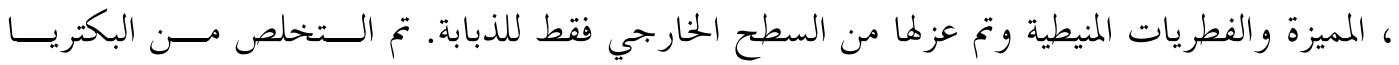
الموجودة في معي الذبابة باستخدام المضاد الحيوي نورفلو كساسين و ذلك لمعرفة دور هذه البكتريسـا في

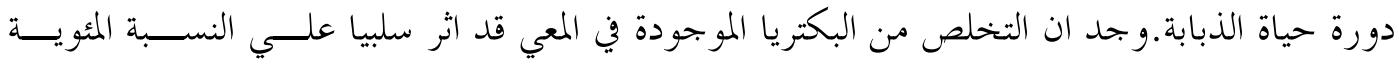

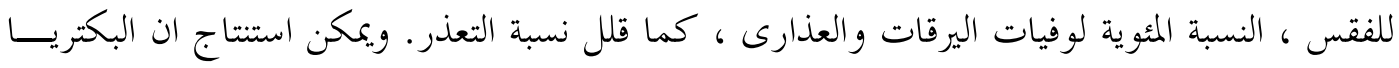

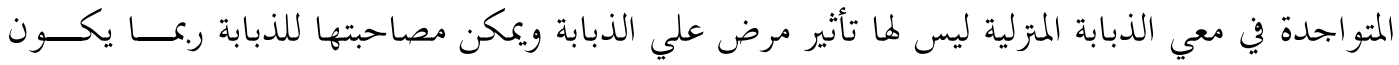
تبادل منفعة او معايشة. 